\title{
Consumer Expectation Analysis As A Basis For Determining Service Performance To Improve Customer Loyalty
}

\author{
Pieter D. Samadara ${ }^{1}$, Krysler K. Adoe $^{1,}$ Roberth M. Noach ${ }^{1}$ \\ \{pietersamadara@gmail.com, ,krysler.adoe@gmail.com,robert.niach95@gmail.com\} \\ State of Polytehnic Kupang East Nusa Tenggara Province ${ }^{1}$
}

\begin{abstract}
This study titled Analysis of consumer expectations as the basis for identifying customer retention services (survey among consumers shopping in several retail stores in Kupang City). The aims of this study are; (1) what consumers expect at retail outlets, (2) which services are provided by retail outlets, and (3) whether there are differences between consumer expectations and retail store performance. The study method used in this study was a descriptive survey. The population in this study was consumers shopping in several retail outlets in Kupang City. The sample in this study was determined to be 250 consumers. Data obtained with the questionnaire. In order to answer the problem, to achieve the research goals and to analyze the data, the differential t-test is used as the analysis tool. To answer the formulation of the first and second problems, a different test of a sample t-test is used. Meanwhile, another test for the independent sample t-test is used to answer the third problem. Both test tools are available in the SPSS software. The results showed that there were differences between consumer expectations and the performance of the services provided by retail stores in Kupang City. Retail stores are not yet fully able to meet consumer expectations.
\end{abstract}

Keywords: consumer expectations, service, consumer satisfaction, consumer loyalty.

\section{Introduction}

The level of competition among retailers in Kupang City is currently increasing. This is indicated by the growing number of retail shops starting from small, medium to large retailers. This competition will be a challenge for these retailers to win the competition in attracting the attention of consumers and retaining them to become customers of these retail stores.

Consumers who are interested and willing to become customers of a retail store are loyal consumers. [1] says that customer loyalty is a customer commitment to a brand, store, or supplier that is based on a very positive nature in long-term purchases. Consumers who are loyal to a retail store are very important goals or targets for a retail store. Loyal consumers means that consumers are satisfied with the products and services provided by the retail store.

[2] [3]; [4]; [5]; [6] said that customer loyalty is determined by customer satisfaction. Flint, Blocker and Boutin [7] say that customer loyalty is obtained when the company can give more than customers expect. Consumer loyalty can be predicted from the level of customer satisfaction obtained during the use of a service product, with indicators of no customer complaints, a feeling of satisfaction with the overall product, conformity to expectations, and expectations exceeded. 
Chiou [8] said that customer satisfaction is achieved if the actual service performance is greater or equal to consumer expectations of the services provided. [9] say that customer satisfaction is a feeling of pleasure or disappointment experienced by someone after comparing the performance of the product received with the expected product performance. If the performance received is below what is expected, consumers will feel dissatisfied, and vice versa the performance received is as expected, consumers will feel satisfied, and if the performance received exceeds expectations, consumers will feel very satisfied. The service performance of a retail store is a measure of the quality of service or services provided by a retail store to its consumers. The demand to display optimal service performance for a retail store is a must.

Based on the description above, it is important for retail stores to know; (1) the expectations of consumers who shop at retail stores, (2) the performance of services provided by retail stores, and (3) is there a difference between consumer expectations and the performance of services provided by retail stores?

\section{Review Literature}

\subsection{Retailing and Retailer}

[10] say that retailing is the whole activity or activities carried out by traders with a view to offering goods and services to be sold to consumers. [11] says that retailing is retail sales which includes all activities that involve selling goods and services directly to end consumers for personal, not business use. [12] say that retailing is retail sales which is the last part of the marketing process where the various functions of the seller, the habits of a store or the determination of services and buyers, and individual consumers, which are primarily intended to carry out the exchange of goods daily necessities and services for the purpose of personal, family or household use.

Based on the description above, it can be said that retailing or retail sales are activities involving the business of selling goods or services directly to consumers for personal, family, or household uses and not for business. While retailers can be said as retail sellers or who carry out retail sales.

\subsection{Consumer Expectation}

The customer is an individual who continually and repeatedly comes to the same place to satisfy his desires by having a product or getting a service and satisfying the product or service [13]. Every consumer who enters a store has expectations about how far his needs and desires will be satisfied and fulfilled. Not all consumers have the same expectations about the level of service, price of goods, completeness of goods and quality of goods from a store, therefore retailers must choose a part of the market where the needs and desires of consumers who are in that part of the market can be met properly.

To measure the level of consumer expectations, researchers use the opinions of [13] about factors that influence consumer expectations of a retail store, namely; (1) The right place and time, (2) Store atmosphere, (3) Merchandise, (4) Price, (5) Information and Interaction, and (6) Services provided. 


\subsection{Service Performance}

Cronin and Taylor [14] say that service performance is the performance of services received by consumers themselves and assess the quality of the service they really feel. Richard L. Oliver [9] said that service performance is an evaluation of consumers for products or services based on certain consumption experiences.

\subsection{Customer satisfaction}

[14] [15] say that customer satisfaction is the level of one's feelings after comparing the performance (or results) he feels compared to his expectations. Furthermore, Day [15] said that customer satisfaction as a customer response to the evaluation of perceived discrepancies between initial expectations before purchase (or other performance norms) and actual product performance felt after its use.

Chiou [8] said that customer satisfaction is achieved if the actual service performance is greater or equal to consumer expectations of the services provided. [16] say that customer satisfaction is a feeling of pleasure or disappointment experienced by someone after comparing the performance of the product received with the expected product performance. If the performance received is below what is expected, consumers will feel dissatisfied, and vice versa the performance received is as expected, consumers will feel satisfied, and if the performance received exceeds expectations, consumers will feel very satisfied.

\subsection{Customer loyalty}

[17] says that customer loyalty is a customer commitment to a brand, store, or supplier that is based on a very positive nature in long-term purchases. [18] say that customers are loyal or loyal to a service product, if the customer shows a regular buying behavior or provides recommendations both directly and indirectly to others about a particular product.

\subsection{Relationship between Expectations, Service Performance, Satisfaction, and Consumer Loyalty to Retail Stores}

A retail store that can win competition and increase customer loyalty is a retail store that is able to increase the satisfaction of consumers who come shopping by displaying service performance that exceeds the expectations or expectations of consumers.

[2] [3] [4] [5] [6] said that customer loyalty is determined by customer satisfaction. Flint, Blocker and Boutin [18] say that customer loyalty is obtained when the company can give more than customers expect. Consumer loyalty can be predicted from the level of customer satisfaction obtained during the use of a service product, with indicators of no customer complaints, a feeling of satisfaction with the overall product, conformity to expectations, and expectations exceeded. Consumers who feel their expectations are met compared to the performance of services received will make them feel satisfied. When they feel satisfied, it will increase their loyalty to the retail store.

\section{Research Method}

The approach in this research is quantitative. The research method used in this research is descriptive survey. The aim is to make a systematic, factual and accurate description, 
description or painting of consumer expectations and the performance of the services provided by retail stores.

The population in this study are consumers who come shopping at several retail shops in the city of Kupang. Because the population is very large, the sample in this study was determined as many as 250 consumers. The sampling technique used was accidental sampling, which is a sampling technique based on population members who happened to be met while shopping and were willing to become respondents [19].

Data collection techniques using a questionnaire that has been tested for validity and reliability. The data analysis technique used in this study was the average analysis and the independent sample t-test difference test. Average analysis is used to calculate the average level of consumer expectations and service performance provided by retail stores. The independent sample t-test different test is used to analyze whether there is a difference between the level of consumer expectations and the performance of services provided by retail stores or not.

\section{Results, Discussion and Conclusion}

\subsection{Results}

The results of the analysis used the Independent Sample t-test, which was preceded by a data normality test and a data homogeneity test. Data normality test using the Kolmogorov Smirnov test shows that data collected from samples come from populations that are normally distributed. Homogeneity test data using Levene's Test shows that the population variance of the two samples is equal (equal variance assumed). Independent Sample t-test results indicate that there is a difference between consumer expectations and the performance of the services provided by retail stores.

Table 1. Results of Testing the Difference between Consumer Expectations and Retail Shop Service Performance

\begin{tabular}{lccl}
\hline \multicolumn{1}{c}{ Statistic Test } & $p$-value & Alpha & \multicolumn{1}{c}{ Keputusan } \\
\hline Normaliy Test of Data & 0,311 & 0,05 & Data comes from normally distributed populations \\
\hline $\begin{array}{l}\text { Homogeneity Test of } \\
\text { Data }\end{array}$ & 0,395 & 0,05 & The two population variables are the same \\
\hline Independent Sampel t-test & 0,000 & 0,05 & $\begin{array}{l}\text { There is a difference between consumer expectations } \\
\text { and the performance of the services provided by retail } \\
\text { stores. }\end{array}$ \\
\hline
\end{tabular}

Source: Data processing, 2019

The results of data analysis using a calculated average of the level of consumer expectations and service performance provided by retail stores, can be seen in the table below. 
Table 2. Consumer Expectations and Service Performance of Retailer

\begin{tabular}{lcccc}
\hline \multirow{2}{*}{ Dimension } & \multicolumn{2}{c}{ Consumer Expectations } & \multicolumn{2}{c}{ Service Performance } \\
\cline { 2 - 5 } & Average & Category & Average & Category \\
\hline The right time and place & 3,98 & High & 3,76 & Good \\
\hline Store atmosphere & 4,07 & High & 3,27 & Good enough \\
\hline Merchandise/Product & 3,94 & High & 3,00 & Good enough \\
\hline Price of Merchandise & 3,99 & High & 3,35 & $\begin{array}{l}\text { Quite } \\
\text { affordable }\end{array}$ \\
\hline Information and Interaktion & 4,16 & High & 3,12 & Good enough \\
\hline Service & 4,16 & High & 3,41 & Good enough \\
\hline Total Average & 4,05 & High & 3,32 & Good enough \\
\hline Source: Data processing, 2019 & & & &
\end{tabular}

Based on table 1 above, it can be seen that there is a difference between consumer expectations and the performance of the services provided by retail stores. Based on table 2 above, it can also be seen that average consumer expectations are in the high range of indicators of accuracy in terms of time and place, store atmosphere, merchandise, prices, information and interactions, and services provided. While the average consumer perception of the performance of the services provided by retail stores based on the above indicators is in the quite good range. This shows that employees are not satisfied with the performance of the services provided by retail stores in the city of Kupang, because their expectations of service performance cannot be fully met by the retail store.

\subsection{Discussion and Conclusion}

Not all consumers have the same shopping time, some consumers who have less time, he will use as little time as possible to shop. To reach consumers like this a retail store must be located close to where they live or where they work and must be operated with the time that allows them to shop. The proximity of a store is more emphasized on the travel time needed by consumers from home to shop or from where they work to shop. There are consumers who have lots of time to shop. For consumers like this shopping is recreation. For those faraway places are not an important issue that pleases them.

Consumers have high expectations for the atmosphere of the shop where they shop. They want comfort in the shop. Therefore, retailers must provide an atmosphere where consumers feel like in their own homes that fits their lifestyle. The atmosphere of the store can be seen from how the merchandise is presented, lighting in the store, store room decoration, the path in the room that separates the parts from one another, music that plays in the store room and fragrances and other attractions that are used. Retail stores must also pay attention to the arrangement of merchandise to be neatly organized according to their respective groups so that it is easy for consumers to get it, because there are consumers who care deeply about these things.

Merchandise is a product offered by a shop for sale. Consumers who will shop have the hope that the merchandise needed and desired are all sold at the stores that he will visit so consumers do not need to look elsewhere, this will save time, energy, and costs incurred by 
these consumers. In addition to the completeness of the merchandise sold, retailers must pay attention to the quality of the merchandise, because consumers are very concerned about it. There are consumers who are willing to spend money to buy goods of good quality.

Consumers who enter a store have expectations about prices. They have general knowledge about the prices of goods sold by a shop. Consumers will usually visit stores that sell merchandise at prices that match their expectations for the merchandise they need and want. Retail stores need to hold product price discount programs for certain times because consumers are very concerned about this.

Many consumers visit a store to gather information that they can use to shop now or in the future. At least a store provides information about what products are sold in the store, information about the services provided and so forth. For this reason, retailers must prepare sales personnel who master the ins and outs of merchandise sold so that consumers will feel satisfied by getting the answers they want, as well as courtesy and friendliness when serving consumers.

Consumers also have expectations about what services are provided by a store before they visit the store. The services provided can be in the form of delivery and installation, warranty, replacement of damaged goods, and other services, such as: provision of free parking spaces, provision of carts for groceries, packaging and gift wrapping as well as groceries, storage of goods and others etc. A consumer expects a free home delivery service. If the store does not provide such services, then the store will not be included in the store considered by the consumer.

\section{REFERENCES}

[1] [Tjiptono, Fandy, 2005, Pemasaran Jasa, Bayumedia, Malang.

[2] Aspizain, Chaniago. 2016. The Effects Of Service Quality And Corporate Rebranding On Brand Image, Customer Satisfaction, Brand Equity And Customer Loyalty: Study In Advertising Company At Tvone.RJOAS, 12(60), December 2016. DOI https://doi.org/10.18551/rjoas.2016-12.26

[3] Minh, Ngo Vu; Huu, Nguyen Huan. 2016. The Relationship between Service Quality, Customer Satisfaction and Customer Loyalty: An Investigation in Vietnamese Retail Banking Sector. Journal of Competitiveness. Vol. 8, Issue 2, pp. 103 - 116, June 2016. ISSN 1804-171X (Print), ISSN 1804-1728 (On-line), DOI: 10.7441/joc.2016.02.08

[4] Djumarno, Sjafar, Oktaviadri, Djamaluddin, Said. 2017. The Effect of Brand Image, Product Quality, and Relationship Marketing on Customer Satisfaction and Loyalty. International Journal of Business Marketing and Management (IJBMM) Volume 2 Issue 10 November 2017, P.P.15-24 ISSN: 2456-4559 www.ijbmm.com International Journal of Business Marketing and Management (IJBMM) Page 15

[5] Javed, Farheen and Cheema, Sadia. 2017. Customer Satisfaction And Customer Perceived Value And Its Impact On Customer Loyalty: The Mediational Role Of Customer Relationship Management. Journal of Internet Banking and Commerce, May 2017, vol. 22, no. S8.

[6] Mustawadjuhaefa, Basrimodding, Muh.Jobhaarbima, \& Ilhamlabbase. 2017. Marketing Mix and Service Quality Effect on Customer Satisfaction and Loyalty of Toyota Cars. Quest Journals Journal of Research in Business and Management Volume 5 Issue 2(2017) pp: 13-23 ISSN(Online) : 2347-3002

[7] Nafisa, Jihan, dan Sukresna, I Made. 2018. Analisis Pengaruh Kualitas Layanan, Harapan Kinerja, dan Citra Perusahaan terhadap Loyalitas Pelanggan melalui Kepuasan Pelanggan sebagai variabel intervening (Studi pada RS. Islam Sultan Agung Semarang). Diponegoro Journal of Management. Volume 7, Nomor 3, Tahun 2018, ISSN: 2337-3806

[8] Ratnasari, Desi (2015), Pengaruh Tingkat Ekspektasi dan Kinerja Pelayanan Terhadap Tingkat Kepuasan Masyarakat Melalui Diskonfirmasi Sebagai Variabel Intervening (Studi Pada Dinas 
Kependudukan dan Catatan Sipil Kota Surabaya), Jurnal Kebijakan dan Manajemen Publik, Volume 3, Nomor 1, Januari - April 2015, ISSN 2303 - 341X.

[9] Kotler, Philip and Kevin Keller, 2010. Marketing Management 13, New Jersey : Pearson Hall, Inc.

[10] Marquardt, R.A., Makens, J.C., dan Roe, R.G.,1983, Retail Management : Satisfaction of Consumer Needs, 3rd ed, Dryden Press, Chicago.

[11] Kotler, P., 1994, Manajemen Pemasaran : analisis, perencanaan, implementasi, dan pengendalian, Ed. 6. Jilid 1, Erlangga Jakarta.

[12] Davidson, W.R., Sweeney, D.J. dan Stampfl, R.W., 1984, Retailing Management, 5th ed. John Wiley \& Sons, New York.

[13] Lupiyoadi, Rambat, 2001, Manajemen Pemasaran Jasa, Penerbit Salemba Empat.

[14] Dharmayanti, Diah., 2006. Analisis Pengaruh Service Performance Dan Kepuasan Sebagai Moderating Variable Terhadap Loyalitas Nasabah Vol. 1, NO. 1, April 2006: 35-43

[15] Tjiptono, Fandy, 2004, Strategi Pemasaran, Edisi 2, Penerbit Andi, Yogyakarta.

[16] Kotler, Philip and Kevin Keller, 2010. Marketing Management 13, New Jersey : Pearson Hall, Inc.

[17] Tjiptono, Fandy, 2005, Pemasaran Jasa, Bayumedia, Malang.

[18] Nafisa, Jihan, dan Sukresna, I Made. 2018. Analisis Pengaruh Kualitas Layanan, Harapan Kinerja, dan Citra Perusahaan terhadap Loyalitas Pelanggan melalui Kepuasan Pelanggan sebagai variabel intervening (Studi pada RS. Islam Sultan Agung Semarang). Diponegoro Journal of Management. Volume 7, Nomor 3, Tahun 2018, ISSN: 2337-3806

[19] Sugiyono. 2013, Metode Penelitian Bisnis. Bandung : CV. Alfabeta 